\title{
Mitinis vandens kodas Antano Vaičiulaičio novelèje „Akmenų laukas“
}

\author{
GABIJA BANKAUSKAITÉ-SEREIKIENE் \\ Vilniaus universiteto Kauno humanitarinis fakultetas, Muitinès g. 8, LT-44280 Kaunas \\ El. paštas Gabija.Sereikiene@khf.vu.It
}

\begin{abstract}
Straipsnyje mitopoetiniu aspektu tiriant vandens hierofaniją analizuojama Antano Vaičiulaičio novele „Akmenų laukas“. Novele konstruojama kaip viena iš pagrindinio veikèjo vaikystès istorijų, „,kelionè ị save“, ị momentą, kai prarandamas „,rojus“ ir prieš akis atsiveria „mirties vartai“. Archetipinę funkciją čia atlieka vanduo, kuris yra gyvybès, mirties, moteriškumo išraiška, kuris skatina prisiminimus, išreiškia ciklišką gyvybės rato judesį, atlieka atminties ir pranašo, apvalymo ir atnaujinimo, išeities ir gelbẻjimo funkciją, simbolizuoja ribą ir kliūtị, jausmus ir svajones, kovą bei neįsisąmonintą pasaulèkūros procesą. Kasdienybès ir ribinių situacijų permąstymas, lūžių ir permainų išgyvenimas atšaukus pasaulietinị laiką, sugrịžus ị kritinị momentą per kartotę ir ritualą leidžia pakylèti A. Vaičiulaičiui gyvenimo tikrovę virš buities, suteikti vaizduojamiems ịvykiams mitinị kodą ir visuotinę vertę.
\end{abstract}

Raktažodžiai: mitas, archetipas, vanduo, kūryba, kartotè

\section{IVADAS}

Pasaulis, žmogus ir jo gyvenimas neretai suvokiamas kaip tarpusavyje sąveikaujančių dalelių koegzistavimas trijose sferose, tam tikras būvis. Kiekvienas žmogų supančio pasaulio sudètinis elementas aiškinamas kaip būtinas ir nepakeičiamas, suponuojantis harmoningą, darnią visumą. Žmogus suprantamas kaip sąmoninga būtybė, gebanti kryptingai dalyvauti pasaulèkūros procese. Kosmoso kūrimosi etapai, sandara, savasis „Aš“, jo paskirtis, egzistencijos prasmé, transcendencijos slëpiniai aiškinami ne tik archeologiniais, antropologiniais, psichologiniais ir kitais moksliniais tyrinejjimais, bet pasiremiama ir archetipais - bendruomeninio supratimo „produktais“, glūdinčiais pasąmonèje, bei mitinio mąstymo struktūromis. Mitinis mąstymas vaizdais neatsiejamas nuo religinès patirties, kuri prilyginama pirmapradei patirčiai. Religingas žmogus, kitaip nei pasaulietis, erdvę išgyvena kaip nevienalytę, kokybiškai kitokią: hierofanijos apraiškos žymi šventą, realią erdvę, kurioje galima pasaulèkūra; šventojo centro stokojanti erdvė yra nešventa, chaotiška, todèl 
nereali, ją reikia ritualu, apeigomis kosmizuoti, sakralizuoti, kad būtų galima ịkurti namus, analogiškus dievų namams, t. y. kartoti pirmapradžius dievų veiksmus [4, 15-16, 47].

Siekimas peržengti istorinị laiką, bandymas atkurti mitinę pasaulèkūros akimirką itin ryškus lietuvių prozininko Antano Vaičiulaičio (1906-1992) tekstuose. Jie atspindi pamatines temas, klausimus, vertybes, archetipus - tai, kas žmogui svarbiausia ir kas veikia jo pasaulèvaizdị. Autoriui rūpimos problemos novelèse koduojamos tam tikros srities gamtos simbolika. Vienų novelių ịvaizdžiai grupuojami apie medžio fenomeną, kitų raktas ị giliosios reikšmès atskleidimą - paukščių pasaulis, kai kurios novelès grịstos vandens stichijos archetipinèmis struktūromis ir mitokūros principais. Nemažai analizuotas autoriaus darbų tradiciškumas ir modernumas, aktualumas, poetika, psichologiniai ir etiniai aspektai, egzistencinès temos, nagrinèti archetipai, kūrinių motyvai (Antano Vaičiulaičio 100-osioms gimimo metinėms skirta konferencija ir leidinys Būties harmonijos ilgesys [3], Aušros Liulevičienès [11], Vytauto Kubiliaus [10], Alberto Zalatoriaus [16], Bernardo Brazdžionio [2], Juozo Griniaus [16] ir kt. vertinimai). Itin nuodugniai ịvairiais aspektais analizuotas Antano Vaičiulaičio romanas Valentina. Tačiau archetipiškumo, mitokūros aspektas kūrèjo novelèse, vandens reikšmès ir simbolika nèra išsamiai tirti. A. Vaičiulaičio kūrybos pasaulis, veikẻjai - tradicinès bendruomenès žmonès. Kai kurie tyrejai yra pažymėję, kad rašytojo vaizduojami personažai artimesni transcendentiniam būties modeliui nei pasaulietiniam. Pasak V. Kubiliaus, A. Vaičiulaičiui literatūra yra žmonių bendrumo, dvasinio prado, amžinybès ilgesio išraiška, jo istorijose nèra liūdesio ir maištingos nevilties, vyrauja džiaugsmingas visuotinès harmonijos išgyvenimas, žmogus ramiai siekia šventiškos palaimos, nes tiki, kad dangaus vartai jam iš tiesų atsivers [10, 42, 33]. Kita vertus, pasak M. Eliade’s, bet kuris žmogus, net ir pasirinkęs pasaulietišką gyvenseną, iš dalies vis tiek esti religinèje patirtyje. Mažiau nagrinètos Antano Vaičiulaičio novelès analizė šiuo aspektu yra nauja ir aktuali viso rašytojo kūrybinio paveldo interpretacijai.

Straipsnio tikslas - išanalizuoti A. Vaičiulaičio novelę „Akmenų laukas“ vandens hierofanijos aspektu. Straipsnio uždaviniai: aptarti mitinio mąstymo ir archetipo sampratas, panagrinėti vandens simbolikos reikšmę novelès pasaulèvaizdžio sistemoje. Tyrimo metodas mitopoetinis: remiamasi J. Puhvelo ir E. Meletinskio mitinio mąstymo samprata, C. G. Jungo ir M. Eliade’s archetipinio modelio apibrèžtimi, „,amžinojo sugrižimo“ ir kartotès, ritualo sampratų jungtimi kaip metodologiniu ịrankiu, leidžiančiu interpretuoti novelès mitinị erdvèlaikị ir veikèjų atkuriamus pirmapradžius pasaulèkūros veiksmus, paliudytus dievų, aktualizuoti vandens kaip pamatinès stichijos funkcijas; taip pat pasitelkta kosmogoninès vandens reikšmès aptartis pagal G. Bachelard’ą.

\section{MITAS - ARCHETIPAS - KARTOTE்}

Mitas „fiksuoja mąstymo būdus, kurių dèka žmonių grupè suvokia ir atpažista save, kaupia žinias ir pasitikejjimą savimi, aiškina savo pačių ir aplinkinio pasaulio kilmę bei egzistavimą, o kartais bando nuspèti ir ateiț““ $[13,2]$. M. Eliade’s teigimu, mitai sudaro pirminių apreiškimų in illo tempore visumą, „byloja apie tai, kaip kas nors atsitiko, pradejo büti. <...> kalba tik apie realius dalykus, apie tai, kas realiai ịvyko, apie tai, kas apsireiškè visa pilnatve“ $[5,67]$. Dievai ir protèviai pirmapradejje kūryboje perteike civilizacijos pagrindų žinias, kad amžinasis sugrižzimas ì pačią pradžią ir pirmapradžių veiksmų kartojimas modeliuoja bei moderuoja individų ir kosmoso, kuriame nuolat esti pirmykštis žmogus, buvimo būdą. Tai - susiliejimas su būtimi ir dalyvavimas joje. Mitinis mąstymas gamtą ir žmogų suvokia kaip vienį, neskiria objekto ir subjekto, to, kas materialu ir idealu, vienkartinio ir daugkartinio, kas statiška ir dinamiška, amžina ir laikina. Etnologo Bronislavo Malinovskio teigimu [12, 38], mitas atlieka 
praktinę funkciją palaikydamas tradicijas, genties kultūros nenutrūkstamumą, kodifikuoja mintị, stiprina moralę, siūlo tam tikras elgesio taisykles, sankcionuoja apeigas, racionalizuoja ir pateisina socialinę sanklodą; pragmatinė jo funkcija siekia individo bei visuomenès gerovès ir dermès su socialiniais bei ekonominiais veiksniais.

Mitinis mąstymas, jungiantis praeitị ir dabartị, perteikia archetipines struktūras. Archetipų teoriją pagrindè C. G. Jungas, tyrinėdamas sapnus ir remdamasis analogijomis iš mitologijos. Jo nuomone, archetipai yra tam tikra psyche struktūra, igimta kiekvienam žmogui [7, 221]. Archetipo sąvokos suvokimas visada yra gana problemiškas, nes neretai manoma, kad archetipai reiškia tam tikrus apibrèžtus mitinius vaizdinius ir motyvus. Tai yra instinktyvi linkmė ir kartu sąmoninga tendencija (polinkis) atkurti tam tikro mitinio motyvo, mitologemos išraiškas (pavaizdavimus). Išraiškos gali labai skirtis detalèmis, tačiau nenukrypsta nuo pagrindinio modelio. Archetipai gali iškilti netikètai, tarsi instinktai, ir pasireikšti fantazijomis, simboliniais vaizdiniais, kurių kilmé nežinoma; jie atsikuria bet kuriuo metu ir bet kuriame pasaulio krašte [8]. C. G. Jungas teigia archetipą esant dalimi objektyvios psichikos, dinamišku vaizdiniu, kurị suprantame per nepriklausomo veikejjo išgyvenimą $[9,143]$.

M. Eliade apie archetipus samprotauja panašiai teigdamas, kad tai tipiniai žmogaus elgesio modeliai, turinio neturinčios grynosios formos, slypinčios žmogaus psichikoje ir lemiančios jo elgesị. Kiekvienas simbolis, vaizdinys, objektas, taigi ir mintys, jausmai, situacijos, veiksmai, turi savo archetipinị modelị - bendruomenès ir kiekvieno jos nario pasąmonejje glūdinčią nepaaiškinamą visuotinę pasaulio ir tikrovès sampratą. Tokios struktūros aptinkamos senovès visuomenių mąstysenoje, jomis grindžiama kasdienè veikla, darbai, aiškinamas žmogaus buvimas pačia bendriausia prasme. M. Eliade’s teigimu, tyrinejjant senovès visuomenių žmonių elgesị, galima perprasti būties ir tikrovès sampratas, kurios gali būti traktuojamos kaip esminès pasaulèvokos ašys [4,7]. Būtis ir tikrovè, metafizinis archajinis pasaulis aiškinamas nesąvokine kalba ir atsiskleidžia per simbolius, mitus ir ritualus $[4,7]$. Kartojimas - svarbiausias archetipinių struktūrų aspektas - padeda joms susidaryti, formuoja jų reikšmę $[4,8-9]$. Taigi archajinei sąmonei svarbiausia yra tai, kas sakralu, o sakralu tai, kas „kosmogoniška“, kas esti kūrimo pradžioje, kas gali ir turi kasmet kartotis pagrindiniame tam tikros tradicijos rituale. Religingą žmogų didingesnio, paslaptingo ir intuityviai tesuvokiamo pamėgdžiojimas, ritualizavimas artina prie nežemiškumo, teisingumo, prie kažko, kas buvo ir tebèra žmonių siekiamybè, idealas, vienintelis ir teisingas kelias, galintis palengvinti žmogaus būtị ir bent priartinti prie amžinumo.

\section{VANDENS HIEROFANIJOS SĄSAJA SU „AMŽINUOJU SUGRIZZIMU“}

Mitinio mąstymo struktūros apima pagrindines gamtos stichijas - orą, žemę, ugnị, vandenị. Kaip teigia M. Eliade, bet kokia struktūra, forma, sankūra, kūryba negalima be vandens, nes be jo negali būti jokios formos. Būtent universali vandens simbolika sujungia ir pagrindžia visų kitų sferų pavienių hierofanijų apraiškas. Vandens stichija neprilygsta jokiai kitai, tarsi visko „branduolys“ yra belaikè: „nes vandenys buvo anksčiau už žemę“, „vandenys simbolizuoja bendrą potencialumo visumą; jie yra visų būties galimybių fons et origo, telkinys; jie yra pirmesni už bet kokią formą ir laiko bet kokią sankūrą " $[5,91]$. Nugrimzdimas simbolizuoja sugrị̌zimą ì pirmapradę beformę būseną, chaosą. Iškilimas (pvz., salos mituose) - chaoso suvaldymas, formos igavimas, erdvès kosmizavimas. Vandenys neturi formos, forma galima tik virš vandens $[5,92]$. Tad sąlytis su vandeniu pažymètas ir gyvybès, ir 
mirties ženklais, nes nauja gyvybe įmanoma tik po laikino užgesimo (periodiškas tvanas, žemynų nuskendimas, îšventinamoji krikšto mirtis, nuodėmių nuplovimas, t. t.).

Taigi vanduo yra ypatingas pirmapradis objektas. Dažnai jis pavadinamas gyvybės šaltiniu, jam suteikiama pagrindinės gyvybės egzistencijos sąlygos reikšmė. Pirmapradis vanduo, èmus veikti kokiai nors šventybei ar iš vandens pasirodžius kokiai nors gyvybės sèklai, užuomazgai (lotosui, kiaušiniui) ar pan., nugali chaosą ir sukuria kosmosą - sunaikina tamsą ir pasẻja gyvybę, o vẻliau nepaliaujamai rūpinasi ja, jos išlikimu ir tęstinumu. Tad vanduo atliepia abu pasaulio kūrimosi procesų polius - neigiamą (chaosą) ir teigiamą (kosmosą). Šis vandens dvilypumas dažnai grindžiamas įvairiais įvaizdžiais. Neretai vaizduojami klaidūs, pragaištị nešantys jūrų vandenys, audros, visa užliejantis ir pražudantis tvanas, derlių sunaikinančios liūtys. Dažni ir troškuli malšinantys, gyvybę palaikantys, nuo sausrų ar gaisrų gelbejjantys, apvalantys, augmeniją atgaivinantys vandenys. Toks elemento dvejopumas sietinas su gamtos, pasaulio, gyvybès ciklų samprata ir vandens svarba joje. Vanduo periodiškai atnaujina pasaulì, apvalo jị, ịkūnija tobulèjimo, amžinumo, nenutrūkstamumo idèją.

Daugumoje veikalų vandens stichijos simbolika dažniau siejama su apatine Kosmoso ar Pasaulio medžio sfera, su požemiu ir horizontalumu, su perẻjimu iš mirties, nebūties i žemès būtị, toliau kylant vertikale link dangaus ir ugnies ị dievų sferą. Pats vanduo yra axis mundi [plg. 5, 30], vartai aukštyn arba žemyn, jungiamoji vertikalioji žemės ir dangaus ašis. Taigi vanduo - būtina, veiksmingumu pažymèta stichija, pati atliekanti veiksmą, kurianti, sudedamoji pasaulio objektų medžiaga, keliaujanti per tris pasaulio sferas.

Veiksmas, ejjimas bendriausia prasme suvokiamas kaip kelias, kelionè - pirmiausia ị save, $\mathfrak{i}$ savo esybès centrą. Jis sudètingas, nes tai perẻjimas iš chaoso, mirties ị gyvenimą, realybę, tvarką. Tai iniciacija, èjimas ị veiksmingą būtị. Tai ir kūrybos aktas, Pasaulio sukūrimas. Vanduo, amorfiškas ir neišreikštas, paskatina kosmizavimą, kūrybą per auką, kraują, kuris yra tas pats vanduo. Sugyvinimas, tikrasis gyvenimas, sudvasinimas turi būti paliudytas dievų, siela suteikiama per auką, aktą, ritualą (per prototipą, kartojimą). Daiktas ar veiksmas yra tikras tiek, kiek pamėgdžioja ar atkartoja archetipą. Tad reali tikrovė grindžiama kartojimu arba bendrininkavimu. Mègdžiojant archetipus, atšaukiamas istorinis (žemiškasis) laikas, kartojamas pirmasis veiksmo kartas ab origine [4, 22]: „Kaip îprastinę erdvę panaikina Centro simbolika $<\ldots$. , taip ir kiekvienas prasmingas archajinio žmogaus veiksmas, kiekvienas realus veiksmas, t. y. kiekvienas archetipinio veiksmo pakartojimas, pristabdo trukmę, panaikina ịprastinị laiką ir susieja su mitiniu laiku“ $[4,38]$. Pasaulietinio laiko atsisakymas išreiškia vidinị archajinio žmogaus poreikį, bandymą atkurti buvusị ryši su Būtimi. O noras atmesti istoriją, mėgdžioti archetipus liudija, kad žmogus siekia amžinumo ir tęstinumo, ginasi nuo nebūties baimès, siekia išlikti. Kolektyvinė atmintis nepripažista istorijos, ji išlaiko tik pavyzdinius modelius, teigia amžinąją idejją, ja pažymi konkretų istorinị îvykị ar istorinị asmeni, atmesdama istoriškumą ir asmenybiškumą, palikdama tik simbolizuojantị faktą ar herojų (didvyrị). Atsisakyti istorinio laiko padeda iliuzija, skaitymas, kūryba, amžinojo momento, paliudyto dievų, ilgesingas troškimas, Didžiojo Laiko pasiilgimas, harmonijos poreikis. İkvèpimas, palaimos būsena, skaitymas, „žmogiškojo meno kūriniai yra dieviškojo meno pamėgdžiojimas“, „todèl dievų veikla, teikianti didžiausią palaimą, yra kontempliacija. Todèl ir žmonėms didžiausią palaimą teikia ta veikla, kuri yra artimiausia dieviškai veiklai“ $[4,35]$.

Amžinybès laikas cikliškas, jis nenutrūkstamai sukasi ratu, tai laikas be konflikto. Pasak M. Eliade’s, žmogui būdingas ontologinio rojaus, tobulybės, buvusios ab initio ilgesys [5, 66] ir tikejjimas, kad dievai ir protèviai pirmaprade kūryba perteikè ir civilizacijos pagrindų žinias, o amžinasis sugrižzimas î pačią pradžią - sugrị̌zimas ị tikruosius, realius namus, $\mathfrak{i}$ 
būties esmę, pradžią, lopšį, suteikiantis saugumo jausmą ir galimybę pasijusti tikraisiais pasaulio kūrèjais - dievais, dievybèmis ar herojais. Ritualas „kontroliuoja“ vidinę visatos dialektiką kartu su kartote, besiginančia nuo atsitiktinių ịvykių. Jis iš destrukcijos ir chaoso grąžina i tvarką, darną ir harmoniją, taigi - kosmogoniją, leidžia peržengti profaniškaji laiką. Žmogus kartoja Pasaulèkūros akta - ritualas, dieviškasis modelis, archetipas, sugrąžina į mitinị pradžios meta $[4,24-25]$.

\section{„PRARASTOJO ROJAUS“ ŽENKLAI NOVELĖJE}

Antano Vaičiulaičio novelè „Akmenų laukas“ - retrospektyvus pasakojimas apie vaikysteje išgyventą îvykį, galbūt faktą, kuris, praradęs savo istorines šaknis, gali pasikartoti bet kada ir bet kurioje vietoje kaip savo gyvenimo, savo namų tvèrimo pavyzdys, individo akistata su bendruomenès sukurtu išnaudojimo mechanizmu, kovos už laisvę tragizmo idejja. Novelè konstruojama kaip pagrindinio veikejo vaikystės viena iš istorijų, kaip „kelionè ị save“, kaip tam tikras „auksinis laikas“, kuris baigèsi svetimiems ịsiveržus ị vaikystės užgyventą erdvę. Tai kelionè ị momentą, kai prarandamas „rojus“ ir prieš akis atsiveria „mirties vartai“. Kasmetinis važiavimas pas giminaičius pasakotojo prisimenamas kaip ritualinė kelioné, kaskart detaliai atgaminant aplinką. Vaizdai regejjimo lauke plaukia kaip vanduo - pasireiškia vandens hierofanija. Pirmiausia žvilgsnis stabteli ir fiksuoja kiemų svirtis; novelès kontekste jos turi centro simbolikos vertę - reprezentuoja šulinị, taigi - vandenị. Miesto centrą rodo bažnyčia. Užmiesčio centras - dvaras - mena istoriją apie Napoleoną. Tai sakralizuotos erdvès. Malūnas suteikia mistiškumo, nelaikiškumo: „Nuostabiausias dalykas man toje kelionèje būdavo kukurūzų laukas dvaro žemėse ir didelis vejjinis malūnas, kurị pravažiuodavome beveik po pat sparnais, aukštai besigraibstančiais po orą ir vèl krentančiais žemyn su išpūstu ir plezdenančiu audeklu. Ratų girgždèjimas, storas velenas, prie kurio laikèsi sparnai, miltais apdulkèję langeliai, durys, pro kurias karojo nuleistos grandinès, ir sienojas malūnui ị vejją atkreipti buvo man tokie įdomūs ir paslaptingi kaip pasaka" $[14,238]$. Mitiškai vaizduojama ir Šilbalių sodyba, kurioje augo virš visų kitų medžių iškilęs senas ąžuolas, sietinas su Pasaulio (arba Gyvybès) medžio ịvaizdžiu: „Už gerų varsnų nuo malūno sukdavome ị šunkelį ir toli jau pamatydavome Šilbalių dẻdès trobas. Tuoj išskirdavom jas iš aplinkinių ūkių, nes gale pirkios augo ten ąžuolas, aukštesnis už viso sodžiaus medžius ir su nukaršusia viršūne " [14, 238]. Erdvę kosmizuoja bei sakralizuoja ir beržynèlis: „Visados, kai tik išvysdavau Šilbalių namus, akys man nusišviesdavo ir širdis linksmai šokteldavo: gera ir smagu buvo žiūrèti i tuos beržus, kurie baltavo aplink visą sodybą“ $[14,238]$. Apvaldyta erdvė asocijuojasi su dieviška būtimi, todèl sukelia palaimos būseną [14,31-34]. Šiai kelionès metu regètai sakraliai, užgyventai erdvei oponuoja nevienalytė erdvė galulaukejje, užribio zonoje. Prisiminimų vaizdai nustoja „plaukti“, vandens hierofanija perkeliama ị apleistą, civilizacijos „užmirštą“ vietą.

Novelès veiksmo centras - Kartuvių kalnelis, loma ir Kregždès upelè - teritorija, kurią pasakotojas pakrikštija „karalystės“ vardu. Ši vieta religingam žmogui suskaldyta: Kartuvių kalnelis simbolizuoja mirtį, praeitị, išnykusią civilizaciją, taigi buvusị pasaulèkūros centrą („Savo vardą buvo gavęs nuo to, kad ant jo baudžiavų laikais korè žmones" [14, 238]), turi neigiamą konotaciją; loma atspindi pirmapradi chaosą, yra neapgyvendinta. Upelis, tekantis vanduo per kalneli ir apjuosiantis dykrą, kaip hierofanija sujungia minètas zonas ir rodo mirties ir gyvybès (kregždè - gyvybès, atsinaujinimo nešèja), egzistencijos ir transcendencijos vienį, istorinio fakto tapimą mitiniu ịvykiu, erdvẻlaikio permanentiškumą, potencialią chaoso virsmo kosmosu vietą. Zonas vienija pirmapradè, bet nevienareikšmé medžiaga - akmuo. Lomoje jis gali simbolizuoti centrą, būti pirmaprade pasaulèkūros medžiaga. Kalnelio akmuo („Dykas 
buvo tas kalnelis, be medžio, išraustas ir akmenų pilnas“ [14, 238]) gali sietis ir su mirties ìrankiu - nusidejèliai užmètomi akmenimis.

Vanduo skatina prisiminimus ir pažadina archetipišką nesąmoningą pirmapradès pasaulèkūros procesą, novelèje pasireiškiantị ritualinès kovos vaizdiniais. Kova, pažymèta kartojimu, yra simbolinè, liudijanti šventybès, amžinumo poreikį. Besidžiaugdami vandeniu ir maudynèmis vaikai nejučia atkartoja pirmapradị veiksmą, apsivalymą, pašventinimą: „Sušilę ir pailsę pūkšteldavome ị Kregždès upelę, kuri skaidri gurguliavo per akmenis, ir klegėdami maudèmès, taškydamiesi ir vienas kitą niurkydami ị vandenį “ $[14,238]$. Novelès veikèjai tarsi atgimsta - nuovargị, kaitrą, susikaustymą panaikina vanduo, sąlytis su juo; vanduo neigiamus pojūčius paverčia teigiamais, išsklaido nemalonią būseną ir suteikia smagumo, nuoširdaus džiaugsmo, laimès. Vaikai atgimsta tarsi po krikšto, igyja dieviškumo. I pirmapradiškumą ir rituališkumą nukreipia klegesio, šūksnio motyvai: „Sulig savo riksmu jisai pasileido bėgti prie vandens, šokinėdamas kaip kumeliukas, pirmą sykị išleistas ị lauką. Ir mes suklikom ir metèmés prie Kregždès upokšnio. Pribėgome visi kartu“ [14, 242]. Vaikai simbolizuoja ir archajinị žmogų (maudosi nuogi), atsidūrusị chaotiškoje, dar neapgyvendintoje, todèl tinkamoje pasaulèkūrai erdvèje.

Aplink vaikus esti viskas, ko reikia pasaulio kūrimui: žemé, akmuo, kalnelis (priartinantis prie dangaus centras) ir vanduo. Neapgyvendinta, bet tam puikiai tinkama vieta, naujų potyrių ir pažinimo troškimas atspindi sankūrą: „Mums, mažiems padaužoms, jisai [kalnelis - G. B.S.] labai tiko, nes čia ligi soties galejome slapstytis duobėse, gaudytis, akmenimis laidyti i pakalnę, kasinèti lapès olą, kurios galo niekados neprieidavai“ [14, 238]. Ant kalnelio vaikai tarsi archeologai ar pirmykščiai žmonès tyrinėja gamtą, bandydami atskleisti jos paslaptis, empiriškai pažinti jos galią ir įvesti savo viešpatystę. Kaip teigia M. Eliade, „, „..> kiekviena teritorija, užimta siekiant joje apsigyventi ar ją naudoti kaip „gyvybinę erdvę“, pirmiau iš „chaoso“ paverčiama „kosmosu“; tai yra ritualu jai suteikiama tam tikra „forma“, kuri ją paverčia realia. $<$...> Nesuskaičiuojami erdvès, daiktų, žmonių pašventinimo aktai liudija pirmykščio žmogaus pakvaišimą dèl realybès, jo būties geismą “ $[4,13]$. Dykvietės-kalnelio-upokšnio erdvè vaikams tampa karalyste, kurios šventybę kūrè vanduo ir ritualiniai žaidimai: „Mūsų džiaugsmas buvo neapsakomas. Mes šaukème kaip patrakę, šokinėjome, siautėme ir žaidėme laukiniais. Toji dyka dirva, lapių urvais išraustas kalnelis ir ramiai čiurlenantis upokšnis buvo mūsų karalystè, niekam kitam nenaudinga, ir mums nè ì galvą neatejjo, kad kada nors mes šio savo žaismų tyrlaukio netektume" $[14,239]$. Karalystė išreiškia pirmapradę dievišką buveinę, archetipinị būstą, namus. Požiūris ị vietovę kaip ị karalystę liudija erdvèlaikio ypatingumą ir ịprasmina kartotę - vaikai net buvo susikūrę tam tikrą „savosios“ erdvès apvaldymo ritualą: „Nusibodus pliauškytis upelejje, visi eidavome vaikščioti po akmenų lauką. <...> Išsimaudžius mūsų darbas ir buvo visą daubą peršokuoti akmenimis, nepalypstëjus koja žemès. Taikydavos, kad paslydę nusibrẻnydavome blauzdas, prasiskeldavome kelị ar kaktą " $[14,239]$. Vaikai jaučiasi šeimininkais, elgiasi pagal savo susikurtas taisykles, siekia tapti herojais, didvyriais, turinčiais galios užkariauti ir užvaldyti, atlikti sakralizacijos aktą. Kalnelis ir akmenynė jiems - kovos arena, jie varžosi, kuris pirmas užkops, kuris nenuslysdamas peršokuos visus akmenis. Pardavus kalnelị bei lomą, vaikai liūdi, nes jų sakralizuota erdvẻ atimta, kartu atimta teisé i̇ pasaulio perkūrą joje:

„Kai pribėgome, Motiejukas, sumišęs ir lyg sugèdintas, pasakè:

- Tètis užvakar pardavė akmenų lauką. <...>

- O upelį?

- Upelį? - sudvejojo Motiejukas. - Upelio gal nepardavè - jis juk iš toli atbèga“ $[14,239]$. 
Taigi sąsaja su pirmaprade vaikų „karalyste“ išlieka - per vandenį, kuris yra „niekieno“ ir kaip šventybė jungia profanišką erdvę su sakralia. Vanduo siejamas su naujumu, nepatirtais ịspūdžiais ir galimybe tobulèti, suprasti, patikrinti save, sužinoti savo statusą, vertę gamtoje. Šalia vandens žmogų užlieja gaivališka energija, pasąmonèje kyla nevaldomas noras susikauti su stichija, išmėginti savo jègas. Kovos su gamta, stichijos ịveikimo ir kartu susijungimo su ja momento ypatingumą akcentuoja G. Bachelard’as: „ „_..> šuolis ị jūrą <...> vienintelis tikslus, pagrịstas, šuolio ị nežinią vaizdas, kurị ịmanoma išgyventi“ $[1,272 ;], ~ „<\ldots>$ kai vaikas gimnastikos salëje šokinèja ị tolį ant pjuvenų, jis patiria tik žmogišką lenktynių džiaugsmą. Jeigu jis yra pirmasis šiose varžybose, vadinasi, jis pirmasis tarp žmonių. Ir visiškai kitoks viršžmogiškas išdidumas apima šokant per kliūti gamtoje, vienu šuoliu peršokant upelį! Nesvarbu, kad jis vienas, svarbu, kad jis pirmas. Jis pirmasis gamtoje. Ir ịsitraukęs į nesibaigiantį žaidimą, vaikas šokinejja iš vienos pievos ị kitą, nepaisydamas šniokščiančio vandens pavojų. Ir kiek vaizdų tuomet gimsta! Kiek svajų patiria galybès, triumfo, paniekos nugalètajam skonị. Plačioje lankoje per upelị šokinejjantis vaikas geba svajoti nuotykius, jęgą, polèkį, narsumą" $[1,290]$. Kova vandenyje taip pat susijusi su cikliško gyvybès rato pojūčiu. Būtent galynejimasis su vandeniu ịprasmina mitinio didvyrio, nugalinčio neįmanomas kliūtis, mėgdžiojimą, išreiškia dieviškosios kartotès idejją: „Netrukus mes pliūškeme vandeny, rèkdami ir skandindami vieni kitus, lygiai kaip senomis akmenų dirvos dienomis, kada mes čia žaidème laukiniais“ [14, 244].

Noveleje vaikų ịsivaizduojamą erdvès ịvaldymą keičia tikrasis žmonių ịsikūrimas prie upelio - dykvietę sèkmingai apdirba žemès plotą nupirkęs Baltrus Žirgelis ir jo šeima. Tačiau įsikūrimas nèra lengvas. Vaikai nuolat seka „savosios karalystès“ likimą, nesąmoningai išreikšdami „prarastojo rojaus“ ilgesị, liudydami norą atmesti istoriją, žemiškąji laiką, nesukurtajji, nešventą pasaulį, laiką ir erdvę.

Ūkininkas savuosius namus renčia iš akmenų, molio, augalų ir būtino sando, sutvirtinančio, sujungiančio elemento - vandens. Kiemo centre - šulinys, dievišką rojų simbolizuoja sodas: „Šilbalių vaikams nebuvo tai naujiena, bet aš, išpūtęs akis, žiūrèjau ị šulinị, kurio rentinys buvo akmeninis, žiūrèjau ị medelius, kurie užveistam sode aplink pirkią žaliavo gležnais lapeliais, ir ị javų laukus, iš lèto vilnijančius, padvelkus vejjeliui tenai, kur neseniai riogsojo akmenys ir kerojo dagiai" $[14,244](*)$. Akmuo - žemès ir vandens darinys, išlaikantis atmintị, simbolizuojantis dievišką galią. Naujakurių namai analogiški dievų buveinei. Prie upelio ganèsi karvè - pagrindinè šeimos maitintoja, taigi pienas, kaip ir vanduo, yra gyvybès šaltinis, penas. G. Bachelard’as pažymi, kad pasąmonei „kiekvienas vanduo yra pienas. Tiksliau, kiekvienas palaimingas gèrimas yra motinos pienas“ [1, 227]. Motina gamta maitina žmogu - ji yra gyvybès teikèja.

Vaikams „praradus“ savo karalystę (ị laukinę žaidimų dirvą vartai jau užkelti), išryškinami pasikartojantys raudonos spalvos ir kraujo motyvai, ịvedamas grèsmingo, pražūtimi grasinančio vandens ịvaizdis. Audra oponuoja dainai, ramiai liūliuojančiai tarsi moteriškas vanduo, užsimezga netikètos lemties laukimo intriga, skleidžiasi destrukcijos nuojauta: „Saulè, raudona ir didelè, grimzdo už girių. <...> Nuo paskutinių saulès spindulių debesys pasruvo krauju, buvo nykūs ir baisūs. Daina nutilo. Mamytè pasižiūrèjo ị tuos kruvinus debesų kalnus <...> ${ }^{\text {" }}[14,245]$. Kraujo motyvas kartojasi: padèdami naujajam savininkui ir jo

(*) Plg. su A. Vaičiulaičio novele „Motiejaus šulinys“ [15], kurioje šulinys, sujungtas su medžiu, atlieka steigties funkciją ir tampa pasaulèkūros ašimi, taip pat padeda veikèjui susisiekti su anuo pasauliu (tarpininko funkcija). Abu objektai harmonizuoja aplinkinę erdvę: pritraukia miško paukščius ir gyvūnus, pasotina ūkio galvijus, suteikia sveikatos ūkio gyventojams ir kaimynams, leidžia suklestèti kaimui. 
sūnui rinkti akmenis, vaikai iki kraujo apsidaužo krumplius. Karo metu besistengią pabėgti iš mirties nagų giminaičiai Šilbalių sodyboje su ja susiduria - išvysta karvę perpjautu kaklu: „Mūsų pasirodymas Šilbalių kieme buvo nepaprastas. Kai ịriedejjom pro vartus, prie tvarto, ant pamestų šiaudų, pamatèm išpūstais šonais nuvirtusią karvę. Jos gerklè buvo perpjauta. Šviežias kraujas gliurgè jai iš žaizdos, gerdamasis ị šiaudus ir žemę. Už kūgio pastebejjome Baltrų Žirgelị. Jis šiaudų gniūžte šluostè nuo dalgio kraują lygiai taip kaip dobilienoje pjovejjas, prieš pasigaląsdamas ašmenis" $[14,246]$. Nutraukiama peno, motiniškumo, naujos gyvybès atsiradimo gija. Šis mirties aktas, atliktas giltinès atributu - dalgiu, rituališkai pažymimas degtine: „nuo šaknų“ [14, 247] - degančiu vandeniu, viena vertus, gydančiu žaizdas, skatinančiu užmarštị, kita vertus, suteikiančiu jègų, agresijos, atimančiu protą. Vandens hierofanija inicijuoja veiksmą. Pralietas kraujas (vandens, virtusio krauju, gliurgimas) pranašauja darnaus ir harmoningo gyvenimo griūtį.

Karas sukelia chaosą kultūrinėje erdvėje, naujakurių sodyboje priešinamasi priespaudai ir išnaudojimui, kovojama už savarankiškumą ir laisvę. Didelių ambicijų turintis ūkininkas nenori skolintis iš kaimyno pinigų, nespejja laiku sumokèti mokesčių duoklès ir jo ūkis išvaržomas. Naujakurys materializavo savo svajonę, suteikè jai formą, susikūrè „dangaus karalystę“ žemejje, tačiau liko bendruomenès užribyje. Profaniškas pasaulis riboja jo, tipiško kūrèjo, laisvę. Nuo Kartuvių kalnelio kaltès prieš bendruomenę, nepaklusnumo, bausmès (tiksliai nepasakyta, už ką buvo kariami žmonės) simbolika „nusileidžia“ ị lomą ir „pažadina“ chaosą - „,atgaivinama“ mirtis. Raudonos spalvos, kraujo motyvas pasikartoja kaip mirties pranašas ir namų erdveje: „I kiemą įsirito brička su antstoliu ir dviem žandarais. <...> Niekas ị juos nesikreipè, tik boba su raudona skara pakilo nuo rąsto <...>." "- Kas daugiau? - klausè antstolis, žvelgdamas čia į tris ūkininkus, kurie nepakilo nuo slenksčio, čia ị bobą su raudona skara ant rąsto, čia vèl ị popieros lakštą, čia vèl ị abu mėsininkus“ [14, 249, 250]. Šeimininkas didvyriškai stoja ị kovą už būvị tarsi pirmykštis žmogus - su kirviu rankose. Vokietis, norèjęs sèti mirtị, tarsi Kainas lieka su žyme, randu. Baltraus Žirgelio krauju pažymima apgyvendinta vieta, susijungia vandens ir žemès stichijos: „Čia išvydau kraujo srovelę, kuri iš Baltraus krūtinès per kaklą ir veidą varvejo ant žemès“ $[14,252]$. Mirtis ištinka prie vartų, skiriančių erdves: žardžio ir kiemo, sakralios ir svetimujų desakralizuotos erdvès. Vandens bespalviškumas, vandens ir pieno baltumas galutinai transformuojasi į raudoną spalvą - tampa vandeniu-krauju, simbolizuojančiu mirtị. Kita vertus, ịsigerdamas į žemę kraujas suteikia galią naujam gyvenimui.

Labai svarbi veikejjo mirties scena - Vaičiulaitis pavaizduoja paskutinį ūkininko žvilgsnị, aprèpiantị jo susikurtąji „pasaulį nuo dangaus iki žemės. Simboliškai susiliejama su žeme, teigiama metafizinè būtis. Religingo pasakotojo vizijoje pakartojamas dvasinis pasipriešinimas, išryškinamas didvyriškumas amžinoje kovoje už savo teritoriją, laisvę, nepriklausomybę, išnaudojimą: „Baltrus Žirgelis susvyravo ir užvertẻ akis aukštyn, lyg dar sykị žvelgdamas ị tą stogą, kurị pernai dengè, ir ị tą padūmavusị dangų, kur liūdnai trileno vyturèlis. <...> Lyg pro kokị gelsvą debesèlị, žaižaruojantị mano akyse, aš regejjau, kaip iš to debesèlio pamažèle išsinèrè Baltrus Žirgelis, persisvèręs per žardžio vartus, kaip jis dar kartą sudrebejo lygiai kaip pirmai ir kaip jo rankos paskutiniu truktelejjimu sugniaužè saujelę žemès" $[14,252]$. Atgimimo per mirtị archetipas realizuojamas pomirtine galimybe sugrižti i gimtąją žemę. Žemė veikejją maitino, teikẻ vilties gyventi ir tobulèti: „Net iki mūsų dienų europiečiai išlaikė neaiškų ryšio su gimtąja žeme jausmą. Tai religinė autochtonų patirtis: žmogus jaučiasi esąs čionykštis, ir šis kosminès struktūros pojūtis smarkiai pranoksta šeimos ar giminystès ryšius. <...> Mirdamas žmogus trokšta sugrịžti ị Motinos Žemės įsčias ir būti palaidotas gimtojoje žemeje“ $[5,99]$. Viena vertus, žemès įdirbimas - tai gamtos 
perkūra. Naikindamas gamtą, žmogus naikina pats save. Kita vertus, „kraujo aukos“ nevienkartiškumas, atnašavimas primena žemės pašventinimą ir suponuoja galimą kosmizuojamos erdvès sudvasinimą, „realumą“, jos pavertimą centru - sodyboje lieka gyventi motina su vaikais. Taigi per kraujo auką sakralizuojama erdvé, paverčiama realia tikrove, tarsi grąžinama į pirmapradị laiką, kai pasaulèkūros procese aukščiausioji, gyvybę teikiančioji ir mirtị nešančioji dievybè buvo Motina Žemè.

Vaičiulaičio novelèje vanduo gelbsti tiek nuo fizinių, tiek nuo dvasinių pavojų. Jis padeda išvengti nemalonių situacijų, apsaugo nuo neigiamų emocijų. Ši elemento galia neretai suvokiama intuityviai, jo trauka jaučiama, kai susiduriama su nesèkme, nežinia, nelaime. Susidūrus su netikèta mirtimi kaip priešprieša gyvybe alsuojančiam pasauliui, žmones apgaubia nežinomybè, netikrumo būsena, prarandamas nerūpestingas vaikystès rojaus pojūtis, vaikai patenka ị suaugusiųjų gyvenimą, kuriame yra nebūties šmèkla: „Pajutau mirtị, kuri man pasirodė baisesnè už mano senelių ir brolių mirtị, - didelė mirtis, netelpanti žmogaus prote ir toje ramioje gamtoje, kur vyturèlis trileno. Suklikęs pasileidau pro Kartuvių kalnelị ị Šilbalius. Už savęs girdejjau šniokštuojant kitus vaikus ir dar mačiau, kaip keliu nudardèjo <...> mèsininkas Leizeris ir kaip ị Kregždès upelès pusę nugąsdinta bėgo žalmargè su teliuku“ $[14,252]$. Išsigandę ir pasimetę, suvokę tragediją vaikai pasileidžia ị namus, ì saugią tèvų erdvę, skubiai išdarda mésininkas, karvè su teliuku (gyvuliai) nubèga prie vandens. Vanduo itin moteriškas, motiniškas - jis apgaubia, savo substancine riba atskiria nuo pavojų ir saugo.

Taigi kasdienybės akimirkos ir pavienių žmonių likimai, vertybės Antano Vaičiulaičio novelèje perauga ị visos žmonijos lemties ir amžinųjų vertybių atsikartojimą laike. Šis universalumo aspektas grindžiamas šventybès, mitiškumo pajauta, nukeliančia ị pradžių pradžią. Rašytojo tekstas nejučia gręžiasi ị archetipus, pirmapradžius ir belaikius, išreiškiančius žmonijos kolektyvinę patirtị. „Amžinojo sugrį̌zimo“, „prarastojo rojaus“ ženklai, gyvybès ciklo elementai per vandens hierofaniją suponuoja kūrinyje ir žmogaus būtị. Novelejje vanduo yra gyvybès, mirties, moteriškumo išraiška, atlieka atminties ir pranašo, apvalymo ir atnaujinimo, išeities ir gelbejjimo, aukos funkcijas, simbolizuoja ribą ir kliūtị, jausmus ir svajones, kovą bei mitinę pasaulèkūros erdvę.

Gauta 20140730

Priimta 20151230

\section{Šaltiniai ir literatūra}

[1] BACHELARD, Gaston. Svajonių džiaugsmas: ugnies psichoanalizė: vanduo ir svajonès: erdvés poetika. Vilnius: Vaga, 1993. 567 p.

[2] BRAZDŽIONIS, Bernardas. Magiškasis Vaičiulaičio kūrybos pasaulis. Aidai [interaktyvus]. 1986, [Nr.] 3 [žiūrèta 201404 24]. Prieiga per internetą:

$<$ http://www.aidai.us/index.php?option=com_content\&view=article\&id=8043:pa\&catid=438:198603\&Ite$\operatorname{mid}=509>$.

[3] Būties harmonijos ilgesys: Antano Vaičiulaičio 100-osioms gimimo metinėms. Vilnius: Lietuvių literatūros ir tautosakos institutas, 2006. 197 p.

[4] ELIADE, Mircea. Amžinojo sugrižimo mitas: archetipai ir kartotè. Vilnius: Mintis, 1996. 161 p.

[5] ELIADE, Mircea. Šventybè ir pasaulietiškumas. Vilnius: Mintis, 1997. 162 p.

[6] GRINIUS, J. Veidai ir problemos lietuviu literatūroje / Visages et problèmes de la littérature lituanienne. T. II. Roma: Lietuvių katalikų mokslo akademija, 1977. 496 p.

[7] JUNG, Carl Gustav. Psichoanalizè ir filosofija: rinktinè. Vilnius: Pradai, 1999. 438 p. 
[8] JUNGAS, Karlas Gustavas. Žvelgiant ị pasąmonę [interaktyvus]. [žiūrèta 201404 20]. Prieiga per internetą: <http://web.archive.org/web/20070129085213/http://perkunas.vtu.lt/psichologija/pasamone/>

[9] JUNG, Carl Gustav. Du traktatai apie analitinę psichologiją: apie pasąmones psichologiją: santykiai tarp Aš ir pasąmonès. Vilnius: Margi raštai, 2012. 304 p.

[10] KUBILIUS, Vytautas. Antanas Vaičiulaitis. Kaunas: Šviesa, 1993. 157 p.

[11] LIULEVIČIENÉ, Aušra. Antanas Vaičiulaitis. Lietuvių egzodo literatūra, 1945-1990. Vilnius: Vaga, 1997, p. 234.

[12] МЕЛЕТИНСКИЙ, Елеаза́р Моисе́евич. Поэтика мифа. Москва: Издательская фирма „Восточная литература“, школа „Языки русской культуры“, 1995. 406 с.

[13] PUHVEL, Jaan. Lyginamoji mitologija. Vilnius: Lietuvių literatūros ir tautosakos institutas, 2001. 303 p.

[14] VAIČIULAITIS, Antanas. Tavo veido šviesa: novelès, padavimai, romanas. Vilnius: Vaga, 1989. $490 \mathrm{p}$.

[15] VAIČIULAITIS, Antanas. Vidurnaktis prie Šeimenos: novelès ir apsakymai. Vilnius: Chicago (Ill.), Ateities literatūros fondas, 1986. $131 \mathrm{p}$.

[16] ZALATORIUS, Albertas. Dėsniai, kurie niekados negęsta. A. Vaičiulaitis. Tavo veido šviesa: novelès, padavimai, romanas. Vilnius: Vaga, 1989, p. 1-37.

\section{Mythical code of water in Antanas Vaičiulaitis's novel "The Field of Stones"}

\section{Summary}

In the paper through a mythical aspect of archetypicality, meanings and symbolism of water, the novel "The Field of Stones" by the Lithuanian writer Antanas Vaičiulaitis (1906-1992) is analysed. The analysis is grounded on the conception of mythical thinking developed by J. Puhvel and E. Meletinskij, and the definition of an archetypal model by C. G. Jung and M. Eliade, "eternal return" and repetition, a ritual connection as a means to approach the real time and being as witnessed by Gods. Moreover, the functions of water as a special fundamental element developed by M. Eliade are actualised - water enables world creation through chaos conversion into cosmos conveying ideas of eternity, self-cognition, and creation. The transformation of water by G. Bachelard is also discussed in the paper.

Antanas Vaičiulaitis's novel "The Field of Stones" is constructed as a self-cognition space of the main character through "eternal return" to "paradise lost". Water plays a special archetypal function in the novel - it is an expression of life, death and femininity, inspires reminiscences, transmits the feeling of a cyclical life circle, performs the function of a memory and a prophet, lustration and resurrection, relates to a way out and salvation, symbolises a boundary and an obstacle, feelings and dreams, fight and a subconscious process of primordial world creation.

Key words: myth, archetype, water, creation, repetition 